\title{
Prevalence of potential enteric pathogens in treated and untreated water sources around Eastern Cape region
}

\begin{abstract}
Background: Fecal contamination of water sources has always been a major safety concern and a factor in determining the need of a continuous treatment program. A routine monitoring program for drinking water sources would provide increased public health protection. The aim of this study was to determine the prevalent rates of potential enteric pathogens in water sources in Eastern Cape.
\end{abstract}

Methods: Water samples (from water surfaces and undergrounds) were collected from treated and untreated water sources. The Colilert method (IDEXX Laboratories, Inc., Westbrook, Maine) was used to screen for fecal contamination and then selective culture media and Rapid 20E API Kit were used to identify different isolates.

Results: of the 80 water sources (from Mthatha, Flagstaff, Tsolo, Mount frere, Libode, .... areas) sampled, there was a widespread contamination with coliforms ranging from...1..to. $>2400 \ldots . . . \mathrm{MPN} / 100 \mathrm{ml}$. Whilst the contamination with $E$. coli remained relatively low in most of the sources, there were high contamination levels $(>2400 \mathrm{MPN} / \mathrm{ml})$ of $E$. coli in water sources from Ntabankulu, Ngqeleni, Libode and Flagstaff. Among the isolated enteric pathogens, Escherichia coli 1 was the most prevalent (41.2\%) followed by Salmonella spp. (17.7\%) and Enterobacter spp. (10\%).

Conclusion: The presence of pathogenic micro-organisms in drinking water may pose a serious health risk to consumers especially the young, elderly and the immune compromised. Therefore there is need for governing bodies to take extra steps in treatment and monitoring programs for safer and cleaner water sources.
Volume I Issue I - 2015

\section{Muringani BN, Obi CL,Apalata T,Vasaikar SD \\ Department of Medical Microbiology, Walter Sisulu University, South Africa}

Correspondence: Muringani BN, Department of Medical Microbiology, Faculty of Health Sciences, Walter Sisulu University, Mthatha, South Africa, Tel 047502 1995, 084986 I 287, Fax 047502 230I, Email beanetsai@hotmail.com

Received: May 6, 2015 | Published: July 29, 2015

\section{Introduction}

In almost all South African metropolitan areas, the consumer is provided with high-quality drinking water, but the situation is different in many rural communities. Duse et al., ${ }^{1}$ noted that about 7 million of the 14million people in rural areas of South Africa still lack safe and clean water. Almost $60 \%$ of the rural community in Mthatha have no access to potable drinking water and still depend on untreated river water for their basic domestic needs. ${ }^{2,3}$ The population of the Eastern cape is largely non-urban and poor, with an inadequate water supply infrastructure. ${ }^{2,4}$ The rural communities of this province comprise both scattered villages and subsistence farmers, and formalized towns. The poverty rate in 1998 was $78 \%$ and only $25 \%$ of households had a tap inside their dwelling. ${ }^{5}$ Yet still, many people depend on untreated water sources for their daily water needs today. ${ }^{6}$ Most communities therefore share water from these sources with animals and use it directly for consumption and household use. The water sources are feacally contaminated and devoid of treatment. ${ }^{7}$ Microorganisms and diseases such as cholera and typhoid occur regularly in SA, with rivers and stream often the source of infection due to a lack of sanitation services. $^{2}$

Enteric pathogens are the major pathogens found in water sources and it has become so important to provide clean water due to the escalating HIV cases (about 10.5\%), which makes communities succumb more to organisms which were previously not harmful to them. ${ }^{8-10}$ Pathogens such as E. coli, V. cholerae and S. typhimurium are usually transmitted to humans by ingestion of contaminated water and foods. Aeromonas and Campylobacter have also been added to the least including other parasitic organisms such as Giardia lamblia. ${ }^{11}$ The impact of waterborne diseases(such as diarrhea) is significant in South Africa. Studies have shown that diarrhea is responsible for about $20 \%$ of all deaths in children under 5 years of age living settlements with rudimentary access to water supply and sanitation. ${ }^{6,12}$

Studies have also shown that waterborne diseases are responsible for an estimated 43000 deaths and 3million incidences of illnesses annually with an associated treatment cost of some 430million ${ }^{3,13}$ Zimbabwe recently became a very good example of the devastating effects of untreated water sources, with a risk of spreading across the South African and Zambian borders due to cholera and typhoid out break. ${ }^{6,14}$ Thus if lack of clean water supplies is not improved, it will continue to cost governments and devastate communities and will be worsened by HIV/AIDS and MDRTB escalating cases, putting a strain on already strained health care facilities. ${ }^{8,15}$

Therefore a routine programme for monitoring drinking water sources would provide increased public health protection since it would result in the detection of specific pathogenic organisms capable of causing infections and diseases in communities.

The study was aimed at determining the prevalence of Entero pathogens in the treated and untreated water sources in the Eastern Cape Province. The Mthatha metropolitan and its surrounding rural communities were assessed. To achieve this goal, water samples were collected from several sources (Rivers, springs, tanks, treatment plants, and taps). 


\section{Objective}

The purpose of this study was to determine the prevalence of Entero pathogenic contaminates in water sources in the Eastern Cape region and compare treated and untreated water sources.

\section{Materials and methods}

\section{Control strains: Escherichia coli 0157.}

\section{Study sites and sampling}

Water samples were collected from 80 different sources which

Table I Results of contamination using colilert method included rivers a round Mthatha and neighboring towns (Tsolo, Flagstaff, Mount. frere, Ntabankulu, Qumbu, Ngqeleni, Moyeni, Bizana, Ngcengane, Mqanduli, Ugie, Mt. Aliff, Alfred Nzo, Ngcobo and Ntsele) and from springs, reservoirs storage tanks, treatment plants and taps (Table 1).

Water samples from the above mentioned sources were collected over a period of 4 months (March-June 2012).

Samples from rivers, springs tanks and treatment plants and reservoirs were directly collected ascetically into $200 \mathrm{ml}$ sterile glass bottles, while the tap water were flushed for approximately $5 \mathrm{~min}$ before the collection of samples into $200 \mathrm{ml}$ sterile glass bottles .

\begin{tabular}{|c|c|c|c|}
\hline \multirow[b]{2}{*}{ Area or Location } & \multirow[b]{2}{*}{ Source } & \multicolumn{2}{|l|}{ Colilert test results } \\
\hline & & Coliform count $/ 100 \mathrm{ml}$ & Escherichia. Coli count $/ 100 \mathrm{ml}$ \\
\hline Mthatha & Mandela west tap & 12 & I \\
\hline Mthatha & Songo store tap & 290.9 & $<1$ \\
\hline Ntabankulu & Mvenyane & 31.8 & $<1$ \\
\hline Ntabankulu & Madwakazana J.S.S tank & $>2419.2$ & $>2419.2$ \\
\hline Libode & Corhana tap & 8.5 & $<1$ \\
\hline Ntabankulu & Dumsi JSS & 2.0 & 1 \\
\hline Ntabankulu & Magqagqeni & 16.9 & $<1$ \\
\hline Ntabankulu & Mazakhele sps & $>2419.2$ & $<1$ \\
\hline Ngqeleni & Nkumandeni clinic tank I & $>2419.2$ & 11 \\
\hline Mthatha-mpheko & Ntabeni communal tap & 10.14 & 70.3 \\
\hline Qumbu & Chulunga treatment plant & $>2419.2$ & 11 \\
\hline Ngqeleni & Ngonyama jss & $>2419.2$ & $>2419.2$ \\
\hline Ntabankulu & Dumsi jss & I & $<1$ \\
\hline Mthatha & Mandela west tap & 52.1 & $<1$ \\
\hline Libode & Admin tap & $<1$ & $<1$ \\
\hline Ugie & 5 -SLB tap & $<1$ & $<1$ \\
\hline Mthatha & & 18.1 & 6.3 \\
\hline Ugie & 7-SLB tap & $<1$ & $<1$ \\
\hline Ugie & $|-32|$ tap & $<1$ & $<1$ \\
\hline Ugie & 5-242 tap & $<1$ & $<1$ \\
\hline Ngqeleni & Nkamandeni clinic Nurses Home Tank 2 & 488.4 & $<1$ \\
\hline Ngqeleni & Mabetshe jss tank2 & $>2419.2$ & $>2419.2$ \\
\hline Ugie & I-278 tap & $<1$ & $<1$ \\
\hline Ugie & $7-253$ tap & 224.1 & $<1$ \\
\hline Qumbu & Thikolwana tap & $>2419.2$ & 118.7 \\
\hline Qumbu & Bunene tap & $>2419.2$ & 2 \\
\hline Ugie & $7-316$ tap & $<1$ & $<1$ \\
\hline Qumbu & Tsilithwa clinic tank & 1046.2 & $<1$ \\
\hline Ugie & $7-318$ tap & $<1$ & $<1$ \\
\hline Ugie & $5-246$ tap & 9.7 & $<1$ \\
\hline Qumbu & Jokwana tap & 1299.7 & 15.3 \\
\hline Mount frere & Nguse river & 214.3 & $<1$ \\
\hline
\end{tabular}


Table Continued.

\begin{tabular}{|c|c|c|c|}
\hline & & Colilert test results & \\
\hline Area or Location & Source & Coliform count $/ 100 \mathrm{ml}$ & Escherichia. Coli count/ $100 \mathrm{ml}$ \\
\hline Mount frere & Nomkholokotho river & 108.1 & 1 \\
\hline Mount frere & Mgungundlovu river & 18.7 & 1 \\
\hline Mount frere & Mbhinga river & 2 & $<1$ \\
\hline Mount frere & Ngqumane river & 101.7 & $<1$ \\
\hline Mount frere & Sigundwaneni river & 435.2 & 4.1 \\
\hline Mount frere & Mdakeni river & 579.4 & 3 \\
\hline Qumbu & Nessie knight hospital tap water & $<1$ & $<1$ \\
\hline Mount frere & Mahlobe spring 2 & 1299.7 & 26.2 \\
\hline Mount frere & Buffalo neck river & 920.8 & $<1$ \\
\hline Mount frere & Ginkqu B & 218.7 & 3.1 \\
\hline Mount Aliff & Water works 2 & 146.4 & 1 \\
\hline Mount frere & Mahobe spring I & 396.8 & $<1$ \\
\hline Tsolo & Bele Zingauka clinic & 135.5 & $<1$ \\
\hline Mthatha & John tuckshop & 55.6 & $<1$ \\
\hline Flagstaff & Lukhqhlambeni pipe water & $>2419.2$ & 98.8 \\
\hline Bizana & Luphilisweni river water & 816.4 & 1 \\
\hline St patricks clinic & Gateway clinic tank 2 & $>2419.2$ & 313 \\
\hline Libode & Ngcolora a/a & $>2419.2$ & $>2419.2$ \\
\hline Bizana & Majazi reservor & 4.1 & 1 \\
\hline Flagstaff & Flagstaff purification plant & $>2419.2$ & $>2419.2$ \\
\hline Flagstaff & Holycross hospital purification plant & $>2419.2$ & 26.5 \\
\hline Libode & Ntonjeni spring & $>2419.2$ & 34.5 \\
\hline Sos tank & Sos tank & 214.2 & $<1$ \\
\hline Qunu & Qunu clinic tank & 686.7 & $<1$ \\
\hline Mthatha & Mpheko clinic nurses home tank & $>2419.2$ & $<1$ \\
\hline Qumbu & Nokutshanya 2 & 41 & 2 \\
\hline Qunu & Qunu clinic tank I & 410.6 & $<1$ \\
\hline Ngcengane & Ngcengane nurses home tank & $>2419.2$ & 1 \\
\hline Ngqeleni & Ngqeleni municipal tap & 152.9 & $<1$ \\
\hline Qumbu & Nokutshanga spring water I & 920.8 & 7.1 \\
\hline Mthatha & Mpheko tap & 32.7 & 8.5 \\
\hline Mqanduli & Makathini river & $>2419.2$ & 93.3 \\
\hline Qumbu & Masimini unprotected spring & $>2419.2$ & 36.4 \\
\hline Mqanduli & Thungwana river & $>2419.2$ & 75.9 \\
\hline Mount frère district & Alfred nzo & $>2419.2$ & 1 \\
\hline Libode & Mbiza stream 2 & $>2419.2$ & 75.9 \\
\hline \multirow[t]{2}{*}{ Mqanduli } & Bakuba spring & 1732 & 55.7 \\
\hline & Nqeleni jss & $>2419.2$ & $<1$ \\
\hline Ngqeleni & Nkaukazi tap & $>2419.2$ & 2 \\
\hline \multirow[t]{2}{*}{ Ngcobo } & Ngcobo local municipality & 30.5 & 1 \\
\hline & Madlangala tap & 1 & 1 \\
\hline
\end{tabular}


Table Continued.

\begin{tabular}{llll}
\hline & & Colilert test results & \\
\hline Area or Location & Source & Coliform count//00ml & Escherichia. Coli count//00ml \\
\hline Moyeni & Moyeni communal tap & 60.1 & $\mathrm{I}$ \\
Alfred nzo municipality & Bhubesi vezinyawo a/a & 4.1 & $\mathrm{I}$ \\
Ugie & WR Ugie reservoir & 75.9 & 204.6 \\
Libode & Mbiza stream & $>2419.2$ & 77.1 \\
Ntsele clinic & Ntsele clinic tank & $<1$ & $<1$ \\
St Patrick hospital & St Patrick hospital & 80.1 & $<1$ \\
\hline
\end{tabular}

Bottles were sealed and properly labeled. Samples were then placed in cooler boxes with dry ice bags and transported to Walter Sisulu university Microbiology laboratory within 2 hrs of collection.

\section{Culture and isolation}

To determine the prevalence of Entero pathogenic contamination, Colilert method involving the screening of faecal contamination and selective media and 20E API biochemical test were used as they are the methods used in the NHLS Laboratory in South Africa.

\section{Colilert method}

Substrate liquid-broth medium (IDEXX Laboratories, Inc., Westbrook, Maine) that allows the simultaneous detection of total coliforms and Escherichia coli (E. coli) was used in its mostprobable number (MPN) format (Colilert ${ }^{\circledR}-18$ and Quanti-tray $\left.{ }^{\circledR}\right)$ for basic screening of faecal coliform was used for basic screening for faecal coliform contamination. Two enzyme substrates are included in Colilert- a chromogen that reacts with the enzyme found in total coliforms (galactosidase), and a fluorogen that reacts with an enzyme found in E. coli (glucuronidase). After 24 hours incubation at $35^{\circ} \mathrm{C}$, a total- coliform-positive reaction turns the medium yellow; an E. colipositive reaction causes the medium to fluoresce under a long-wave ultraviolet light $(366 \mathrm{~nm})$.

Positive and both negative Qaunti-trays were inoculated on MaCconkey agar medium (peptone 20.0, lactose10.0, bile salts 5.0, sodium chloride 5.0, Neutral red 0.075and agar 12.0) for speciation. The isolates were further subcultured on a new MacConkey plate and Mueller hinton agar (beef dehydrated infusion from 300.0, casein hydrolysate 17.5, starch 1.5 and Agar 17.0). Gram stain and oxidase were done on the pure colonies. Organisms were identified as lactose fermenters or non lactose fermenters. These organism which were gram negative were then inoculated onto the RAPID20E API strip for biochemical tests and incubated at $37^{\circ} \mathrm{C}$ for $24 \mathrm{hrs}$ in $\mathrm{O} 2$ The strips were then read and the identification was secured using API plus Computer software. ${ }^{16}$

\section{Results and discussion}

The information obtained in this study is crucial to determine the extent to which water sources may influence infection and disease in the communities. And the level of hygiene on the end user of treated community water taps and tanks.

An analysis of the water samples obtained from different drinking water sources resulted in the indication of faecal contamination or non faecal contamination (Table 1). Use of the selective media and 20E API gave presumptive organisms (Table 2) (Table 3) compared the contamination picture of surface and underground water sources.
Table 2 Enteropathogenic organisms isolated from the water samples

\begin{tabular}{ll}
\hline Organisms isolated & $\begin{array}{l}\% \text { Contamination of water } \\
\text { sources }\end{array}$ \\
\hline Escherichia coli I & $41.2 \%$ \\
Salmonella spp & $17.7 \%$ \\
Vibrio cholerae & $7.5 \%$ \\
Vibrio vulnificus & $1.3 \%$ \\
Enterobacter spp & $10 \%$ \\
Citrobacter spp & $5.1 \%$ \\
Acinetobacter spp & $6.3 \%$ \\
Plesiomonas shigellosis & $1.3 \%$ \\
Pseudomonas spp & $10 \%$ \\
Serratia liquefaciens & $1.3 \%$ \\
Photobacterium damsele & $1.3 \%$ \\
\hline
\end{tabular}

Table 3 Comparison of degree of pathogenic organisms isolated from surface and underground water sources

\begin{tabular}{lll}
\hline Organisms & $\begin{array}{l}\text { Number of } \\
\text { protected sources }\end{array}$ & $\begin{array}{l}\text { Number of } \\
\text { unprotected } \\
\text { sources }\end{array}$ \\
\hline Escherichia coli I & 13 & 28 \\
Salmonella spp & 6 & 8 \\
Vibrio cholerae & $\mathrm{I}$ & 4 \\
Vibrio vulnificus & 0 & $\mathrm{I}$ \\
Enterobacter spp & 6 & $\mathrm{I}$ \\
Citrobacter spp & 2 & $\mathrm{I}$ \\
Acinetobacter spp & 2 & 2 \\
Plesiomonas shigellosis & $\mathrm{I}$ & $\mathrm{I}$ \\
Pseudomonas spp & 4 & $\mathrm{I}$ \\
Serratia liquefaciens & 0 & $\mathrm{I}$ \\
Photobacterium damsele & $\mathrm{I}$ & 0 \\
\hline
\end{tabular}

All the water samples collected from both treated and untreated water sources over a period of 4 months (March-June 2012) showed that $87.5 \%$ were contaminated with $52.5 \%$ presenting with faecal contamination as per the presence of $E$. coli. 
The culture method using selective media showed faecal contamination and the results were about $41.2 \%$ E. coli isolated, $17.7 \%$ Salmonella species and $7.5 \%$ Vibrio cholera as per Table 2.

Enteropathogens were isolated in 69 of the water sources and these pathogens were (E coli, Salmonella spp, Vibrio cholera, pseudomonas spp as per Table 3) Although E. coli is part of the normal faecal flora of humans and animals, some strains can cause severe and life threatening diarrhea. It has also become significant in HIV positive individuals were it can cause life threatening diseases, particularly among children and young infants (2months). In South Africa and most African countries diarrhea is responsible for about $20 \%$ of death with an estimated cost of 3,4billion from a study done in $1998 .^{7,17}$

$E$. coli are capable of causing urinary tract infections, neonatal infections, and intestinal diseases (EIEC, EPEC, ETEC, EAggEC and EHEC). Therefore, the presence of this organism in drinking water sources may pose a serious health risk to communities. Comparison of treated and untreated water sources showed that 41 sources were contaminated by E. coli.

From the colilert results, most of the water sources are characterized by a high number of faecal coliforms and Heterotrophic bacteria, exceeding by far the limit allowed by the South African water quality guidelines for domestic use. Microbial water compliance of $99 \%$, according to SANS 241, and good compliance of $95 \% .^{18}$

Poor sanitation is the most common problem in water contamination. ${ }^{13}$ In most cases, ground water remains the source of main water supply for many communities with Mthatha having $60 \%$ of the households using river water or open springs. ${ }^{2}$ Some communities receive water drawn from the boreholes and well whereas for others, the water is drawn from the boreholes to a reservoir and then delivered to the community through stand pipes. The quality of water may be improved through cleaning of distribution system from the reservoir to the standpipes, addition of disinfectant or the boiling of drinking water before use as contamination of these sources was also noted in this study with organisms such as E. coli, Salmonella, serratia, pseudomonas being isolated as shown in (Table 3 ).

The study supports other findings from other published studies on the challenges for health and water resources in South Africa. ${ }^{13,15,19-21}$ Thus there is need to address the water supply problems in the South African communities.

\section{Conclusion and recommendations}

The study revealed the contamination rate of the waters in and around Mthatha. $82.5 \%$ of the water samples were contaminated with $52.5 \%$ presenting with $E$. coli contamination and only $12.5 \%$ were safe.

The study also confirmed other faecal and environmental contaminations for both open and protected/treated water sources. The study therefore recommends regular monitoring of drinking water sources with more emphasis on communal taps to check for the presence of pathogenic bacteria. Educating people in the communities about waterborne bacteria is also recommended.

E. coli was more implicated in unprotected water sources but was also significantly present in the piped/protected water and organisms like Citrobacter which occur in environments and has been reported to cause opportunistic infections in immune suppressed individuals (respiratory tract, urinary tract and blood) and also neonatal meningitis. ${ }^{22}$ Plesiomonas spp. is an Entrobacteriaceae which is distinguished from Shigella by oxidase test and it is positive and DNase negative which distinguishes it from Aeromonas spp. it has been reported to cause gastroenteritis, followed by septicemia in Immune deficient individuals. ${ }^{23}$ While Photobacterium have pathogenicity derived from their polysaccharide capsular layer and depends on availability of iron. It is an environmental gram negative rod mainly affecting fish previously known as Pasteurella Piscicida .The bacteria spread via infected Phagocytes, mainly Macrophages, the spread can be rapid with a lethal effect affecting tissues with a large number of the Pathogenic bacteria. ${ }^{24}$

Enterobacter cloacae which causes nosocomial infections has been reported as becoming multidrug resistant in other studies. It is also associated with urinary tract and respiratory tract infections in immune suppressed individuals. ${ }^{25}$

Serratia spp. falls under the Enterobacteriaceae and causes respiratory and urinary tract infections rather than gastrointestinal tract in adults, with $2 \%$ nosocomial infections of the bloodstream, lower respiratory tract, surgical wounds and skin and soft tissue. ${ }^{15}$

Pseudomonas spp. presence in most of the piped water sources and this is a concern as it shows that the pipes are not well cleaned or disinfection is not being carried out. In this era of HIV, organisms which were not of concern are becoming significant as they cause problems in immune suppressed individuals thereby worsening their plight, thus there is need for clean water sources. ${ }^{8}$

\section{Acknowledgements}

Mhatha general hospital, Department of medical microbiology Walter Sisulu university, Lottery fund south Africa.

\section{Conflict of interest}

The author declares no conflict of interest.

\section{References}

1. Duse AG, da Silva MP, Zietsman I. Coping with hygiene in South Africa, a water scarce country. Int $J$ Environ Health Res. 2003;13(Suppl 1):S95-S105.

2. State of Rivers Report No 142008 Mthatha river systems/www.dwarf. gov.za

3. Momba MNB, Malakate VK, Theron J. Abundance of pathogenic Escherichia coli, Salmonella typhimurium and Vibrio cholerae in Nkonkobe drinking water sources. J Water Health. 2006;4(3):289-296.

4. Momba MNB, Kaleni P. Regrowth and survival of indicator microorganisms on the surfaces of household containers used for the storage of drinking water in rural communities of South Africa. Water Res. 2002;36(12):3023-3028.

5. May J. Poverty and inequality in South Africa. Report prepared for the office of the Executive Deputy President and the Inter-Ministerial committee for poverty and inequality. Durban, South Africa; 1998.

6. World Health Organization. Enterotoxigenic Escherichia coli (ETEC) Diarrheal Diseases. USA: WHO; 2010.

7. Obi CL, Potgieter N, Bessong PO, et al. Gene encoding virulence makers among Escherichia coli isolates from diarrheic stools samples and river sources in rural Venda communities of South Africa. Water SA. 2004:30(1):37-42. 
8. Obi CL, Ramalivhana J, Momba MNB, et al. Antibiotic resistance profiles and relatedness of enteric bacterial pathogens isolated from HIV/ AIDS patients with and without diarrhea and their household drinking water in rural communities in Limpopo province South Africa. African Journal of Biotechnology. 2007;6(8):1035-1047.

9. Pettifor AE, Rees HV, Kleinschmidt I, et al. Young people's sexual health in South Africa: HIV prevalence and sexual behaviours from a nationally representative house-hold survey. AIDS. 2005;19(14):1525-1534.

10. www.statssa.gov.za

11. Obi CL, Coker AO, Epoke J, et al. Distributional pattern of bacteria diarrhoeagenic agents and antibiograms of isolates from diarrhoea and non-diarrhoea patients in urban and rural areas of Nigeria. Cent Afr J Med. 1998;44(9):223-229.

12. Lehloesa LJ, Muyima NYO. Evaluation of the impact of household treatment procedures on the quality of groundwater supplies in the rural community of the Victoria district, Eastern cape. Water SA. $2001 ; 26(2): 285-290$.

13. Momba MNB, Notshe TL. The microbiological quality of ground water derived drinking water after long storage in household containers in a rural community of South Africa. J Water Supply Res T. 2003;52(1):6777.

14. https://en.wikipedia.org/wiki/United-Nations-Office-for-the-Coordination-of-Humanitarian-Affairs

15. Images courtesy of CDC.

16. http://www.biomerieux.com/en/biomerieux-worldwide/africa/za
17. Pegram GC, Rollins N, Espey Q. Estimating the cost of diarrhea and epidemic dysentery in KwaZulu Natal and South Africa. Water SA. 1998;24:11-20.

18. Department of water Affairs and Forestry. Community water supply and Sanitation: strategic study-National Assessment. DWAF PRETORIA. 1996.

19. Grabow WOK. Waterborne diseases: update on water quality assessment and control. Water SA. 1996;22(2):193-202.

20. Obi CL, Potgieter N, Bessong PO, et al. Assessment of the microbial quality of river water sources in rural Venda communities in South Africa. Water SA. 2002;28(3) 287-291.

21. Jubasi M, Padayachee N. Cholera shock: 14 dead as disease puts 1000 people in hospital. Sunday times, 2003.

22. Whalen JG, Mully TW, English JC. Spontaneous Citrobacter freundii infection in an immunocompetent patient. Arch Dermatol. 2007;143(1):124-125.

23. Niedziela T, Lukasiewicz J, Jackmeck W, et al. Core oligosaccharides of Plesiomonas shigelloides 054:H2 (strain CNCTC 113/92):structural and serological analysis of the lipopolysaccharide core region, the $\mathrm{O}$ antigen biological repeating unit, and the linkage between them. $J$ Biol Chem. 2002;277(14):11653-11663.

24. Barber GR, Swygert JS. Necrotizing fasciitis due to Photobacterium damsela in a man lashed by a stingray. N Engl J Med. 2000;342(11):824.

25. Barnes BJ, Wiederhold NP, Micek ST, et al. Enterobacter cloacae ventriculitis successfully treated with cefepime and gentamicin: case report and review of the literature. Pharmacotherapy. 2003;23(4):537-542. 